\title{
Potential use of two subtropical mangrove species (Laguncularia racemosa and Rhizophora mangle) for nutrient removal in closed recirculating systems
}

\section{Uso potencial de dos especies de mangle subtropical (Laguncularia racemosa y Rhizophora mangle) para la remoción de nutrientes en sistemas de recirculación cerrados}

\author{
Leonardo Moroyoqui-Rojo' ${ }^{1}$, Francisco Flores-Verdugo ${ }^{2}$, Diana Cecilia Escobedo-Urias ${ }^{1}$, \\ Francisco Flores-de-Santiago ${ }^{3 *}$, Fernando González-Farías ${ }^{3}$ \\ ${ }^{1}$ Centro Interdisciplinario de Investigación para el Desarrollo Integral Regional-Instituto Politécnico Nacional \\ (CIIDIR-IPN), Blvd. Juan de Dios Bátiz Paredes 250, Guasave, Sinaloa, México. \\ ${ }^{2}$ Instituto de Ciencias del Mar y Limnología, Unidad Académica Mazatlán, Universidad Nacional Autónoma \\ de México, Av. Joel Montes Camarena s/n, Mazatlán, Sinaloa 82040, México. \\ ${ }^{3}$ Instituto de Ciencias del Mar y Limnología, Universidad Nacional Autónoma de México, Apartado postal 70- \\ 305, Av. Universidad 3000, Ciudad Universitaria, Coyoacán, DF 04510, México.
}

* Corresponding author: floresdesantiago@gmail.com, ffloresd@cmarl.unam.mx

\begin{abstract}
Six silvofishery systems were constructed to estimate the potential use of mangrove seedlings for nutrient removal. Two systems did not contain seedlings (i.e., control treatment), while the remaining systems were divided into separate treatments using two mangrove species (Laguncularia racemosa and Rhizophora mangle). Each system consisted of two water tanks linked by two hoses. The first tank contained 150 poeciliid fishes, while the second contained a biological filter of gravel and sand on the bottom, as well as a hydroponic arrangement of 34 seedlings. Water exchange between both tanks was performed over a 24-h period, every ten days for seven months, and the concentration of nutrients $\left(\mathrm{NH}_{4}^{+}, \mathrm{NO}_{2}^{-}, \mathrm{NO}_{3}^{-}\right.$, and $\left.\mathrm{PO}_{4}^{-3}\right)$ was measured every $8 \mathrm{~h}$. Laguncularia racemosa showed a higher growth rate compared to R. mangle, but there were no differences regarding the growth of fishes among the six systems. Final dissolved inorganic nitrogen removal was $42 \%$ in the control treatment and $90 \%$ in both treatments using mangroves. Dissolved inorganic phosphorus removal was $45 \%$ in the control treatment, $44 \%$ in the $L$. racemosa treatment, and $35 \%$ in the $R$. mangle treatment. Our results indicate that both mangrove species are capable of removing a considerable amount of nitrogen, but phosphorus removal was unsatisfactory.
\end{abstract}

Key words: poeciliid, Mexico, biological filter.

RESUMEN. Seis sistemas de cultivo fueron construidos para evaluar el uso potencial de plántulas de mangle en la remoción de nutrientes. Dos de los sistemas no contenían plántulas (i.e., control), mientras que los sistemas restantes fueron divididos en tratamientos por separado con dos especies de mangle (Laguncularia racemosa y Rhizophora mangle). Cada sistema consistió en dos tanques de almacenamiento unidos por dos tubos. El primer tanque contenía 150 peces poecílidos, mientras que el segundo tanque contenía 34 plántulas en forma hidropónica y un filtro biológico de grava y arena en el fondo. Se hicieron recirculaciones de agua entre ambos tanques cada diez días por un periodo de siete meses. Durante cada recirculación, se midió la concentración de nutrientes $\left(\mathrm{NH}_{4}^{+}, \mathrm{NO}_{2}^{-}, \mathrm{NO}_{3}^{-}\right.$y $\left.\mathrm{PO}_{4}^{-3}\right)$ cada 8 h. Laguncularia racemosa presentó una tasa de crecimiento mayor comparada con R. mangle; sin embargo, el crecimiento de los peces fue igual entre los seis sistemas. El porcentaje final de nitrógeno inorgánico disuelto fue $42 \%$ en el tratamiento de control y $90 \%$ en los tratamientos con $L$. racemosa y $R$. mangle. El porcentaje de remoción de fósforo inorgánico disuelto fue $45 \%$ en el control, $44 \%$ en el tratamiento con $L$. racemosa y $35 \%$ en el tratamiento con $R$. mangle. Los resultados indican que ambas especies de mangle son capaces de remover una cantidad considerable de nitrógeno, pero la remoción de fósforo fue insatisfactoria.

Palabras clave: poecílidos, México, filtro biológico.

\section{INTRODUCTION}

Globally, aquaculture-related activities have grown at an annual rate of $8.8 \%$ over the past 30 years as a result of the increasing demand for aquaculture products (Jensen et al. 2014) and improved production lines (Asche 2008). The annual average consumption of aquatic organisms increased from $16 \mathrm{~kg}$ per person in 2000 to $18.6 \mathrm{~kg}$ per person in 2010

\section{INTRODUCCIÓN}

A nivel global, las actividades relacionadas con la acuacultura han crecido a una tasa anual del $8.8 \%$ en los últimos 30 años debido al incremento en la demanda de productos derivados de la acuacultura (Jensen et al. 2014) y al mejoramiento en las líneas de producción (Asche 2008). El promedio anual de consumo de organismos acuáticos aumentó de 
(FAO 2012). By 2018, more than half of the global demand for aquatic organisms is expected to be met by intensive farming systems, and by 2022, aquaculture is expected to provide an additional 22 million tons of fish (FAO 2012).

Culture systems produce several chemical compounds that can be harmful to the cultured organism and the environment. If these compounds are not eliminated, persistent nutrient accumulation occurs (i.e., eutrophication), particularly in semi-closed or closed recirculating systems with little or no water exchange (Bouwman et al. 2013). Cultured organisms convert about $10-35 \%$ of nitrogen and phosphorus into biomass and the rest is released as organic and inorganic nutrients directly into the aquaculture pond (Shimoda et al. 2007, Herbeck et al. 2014). Consequently, aquaculture effluents contain a considerable amount of nitrogen and phosphorus compounds (Schneider et al. 2005, Buhmann and Papenbrock 2013, Barraza-Guardado et al. 2014, Herbeck et al. 2014). Among these compounds, ammonium $\left(\mathrm{NH}_{4}^{+}\right)$ and nitrite $\left(\mathrm{NO}_{2}^{-}\right)$are toxic to cultured organisms, and nitrate $\left(\mathrm{NO}_{3}{ }^{-}\right)$is toxic only at high concentrations (Camargo et al. 2005). If the waters of these culture systems are discharged without prior treatment, ammonium, nitrite, nitrate, and phosphate $\left(\mathrm{PO}_{4}^{-3}\right)$ can cause eutrophication of the receiving water bodies (Herbeck et al. 2014). Nitrate and phosphate are considered to be the limiting nutrients in freshwater and marine environments (Sundareshwar et al. 2003), and high levels of these nutrients can thus cause massive algal blooms that can affect the biochemical aspects and cycles of coastal environments.

As a result of the environmental problems caused by high nutrient concentrations in aquaculture farms and the consequent restrictions implemented by federal agencies, engineers and ecologists have developed several types of treatments for the optimum use of effluents from culture systems. Some of the most widely used methods are reverse osmosis (Schoeman and Steyn 2003), ion exchange (Kim and Benjamin 2004), electrodialysis (Menkouchi Sahli et al. 2006), activated carbon (Sison et al. 1995), chemical denitrification (Hu et al. 2002), and treatments using microorganisms (Zaitsev et al. 2008). While these are efficient methods for removing nutrients from polluted waters, the operational cost is considerable and developing relatively inexpensive methods to counteract eutrophication is a practical necessity (Páez-Osuna et al. 2003, Huang et al. 2012). Natural and constructed wetlands have been proposed as alternative, costeffective wastewater-treatment systems (Lin et al. 2002, 2003). Aquatic macrophytes in wetlands play an important role in nutrient removal. The processes involved in the transformation of nitrogen compounds in wetland soil are ammonification followed by nitrification and denitrification (Maltais-Landry et al. 2009, Buhmann and Papenbrock 2013). In wetland sediments, $80-90 \%$ of the phosphorus occurs in organic form, some is incorporated by the plants, and a small part occurs in the form of orthophosphate (Buhmann and Papenbrock 2013).
$16 \mathrm{~kg}$ por persona en el año 2000 a $18.6 \mathrm{~kg}$ por persona en 2010 (FAO 2012). Se espera que para 2018, más de la mitad de la demanda global de organismos acuáticos será proporcionada por sistemas de cultivo intensivos. Además, se pronostica que las actividades relacionadas con la acuacultura proveerán 22 millones de toneladas de pescado adicionales para el año 2022 (FAO 2012).

Los sistemas de cultivo contienen varios compuestos químicos que pueden ser dañinos para los organismos cultivados y el ambiente. Si estos compuestos no son eliminados, se presenta una persistente acumulación de nutrientes (i.e., eutrofización), especialmente en sistemas de circulación semicerrados o cerrados donde el intercambio de agua es poco o nulo (Bouwman et al. 2013). Los organismos cultivados convierten cerca del 10-35\% del nitrógeno y fósforo en biomasa y el resto es liberado directamente al estanque de cultivo en forma de nutrientes orgánicos o inorgánicos (Shimoda et al. 2007, Herbeck et al. 2014). Como resultado, las descargas de los sistemas de cultivo contienen una cantidad considerable de compuestos de nitrógeno y fósforo (Schneider et al. 2005, Buhmann y Papenbrock 2013, Barraza-Guardado et al. 2014, Herbeck et al. 2014). De estos compuestos, el amonio $\left(\mathrm{NH}_{4}^{+}\right)$y nitrito $\left(\mathrm{NO}_{2}^{-}\right)$son tóxicos para los organismos cultivados, y el nitrato $\left(\mathrm{NO}_{3}{ }^{-}\right)$es tóxico únicamente en concentraciones altas (Camargo et al. 2005). Si las aguas de estos sistemas de cultivo son descargadas sin un tratamiento previo, el amonio, nitrito, nitrato y fosfato $\left(\mathrm{PO}_{4}^{-3}\right)$ pueden causar eutrofización en los cuerpos de agua donde son descargados (Herbeck et al. 2014). El nitrato y fosfato son considerados nutrientes limitantes en ambientes de agua dulce y marinos (Sundareshwar et al. 2003). Como consecuencia, una concentración alta de estos nutrientes puede causar florecimientos de algas masivos, los cuales pueden afectar el aspecto y los ciclos bioquímicos de los ambientes costeros.

Como resultado de los problemas ambientales causados por las altas concentraciones de nutrientes en las granjas acuícolas y de las restricciones implementadas por parte de agencias federales, ingenieros y ecólogos han desarrollado varios tipos de tratamientos para el uso óptimo de los efluentes de los sistemas de cultivo. Algunas de las técnicas más utilizadas incluyen ósmosis inversa (Schoeman y Steyn 2003), intercambio iónico (Kim y Benjamin 2004), electrodiálisis (Menkouchi Sahli et al. 2006), carbono activado (Sison et al. 1995), desnitrificación química (Hu et al. 2002) y tratamiento con microorganismos (Zaitsev et al. 2008). A pesar de que estas técnicas son efectivas para la remoción de nutrientes en aguas contaminadas, el costo operacional es considerable. Debido a esto, es necesario desarrollar métodos relativamente económicos para contrarrestar las condiciones de eutrofización (Páez-Osuna et al. 2003, Huang et al. 2012). Los humedales naturales y artificiales han sido sugeridos como sistemas económicos para filtrar efluentes provenientes de la acuacultura (Lin et al. 2002, 2003). Las macrófitas acuáticas dentro de los humedales juegan un papel 
Mangrove wetlands are one of the most productive coastal ecosystems in tropical and subtropical regions (Kristensen et al. 2008). They are considered a tolerant group of plants for aquaculture effluents because of their huge demand for nutrients (Yang et al. 2008, Huang et al. 2012, Bao et al. 2013). Moreover, mangroves play a critical role in the removal and degradation of pollutants such as heavy metals, pesticides, and nitrogen and phosphate compounds (Kristensen et al. 2008, Reef et al. 2010, Adame and Lovelock 2011, Bayen 2012). Hence, the use of mangrove wetlands is considered a relatively simple, low-cost alternative for the treatment of aquaculture effluents (Ye et al. 2001, Huang et al. 2012, De-León-Herrera et al. 2015).

In recent decades, mangrove wetlands have been used as a viable option for removing nitrogen and phosphate compounds. For example, Wong et al. (1997) studied the rate of organic nitrogen and carbon removal at two intertidal sites dominated by Kandelia candel and Aegiceras corniculatum, and their results suggest that these two mangrove species have great potential for the removal of nutrients. Tam and Wong (1995) measured the rate of nutrient and heavy metal retention in two types of mangrove soil and found that mangroves act as traps for phosphorus and heavy metals but were less efficient at retaining nitrogen. Wu et al. (2008) studied the potential use of $K$. candel as a secondary treatment of municipal wastewater and their findings indicate that it is feasible to use this species to remove dissolved organic carbon, ammonium, and orthophosphates. In a pilot-scale constructed wetland using K. candel, A. corniculatum, and Sonneratia caseolaris for the removal of organic matter and nutrients, Yang et al. (2008) found that the treatment efficiency of S. caseolaris and A. corniculatum was higher than that of $K$. candel. In an experiment in which Sonneratia apetala was irrigated with three concentration levels of wastewater, Zhang et al. (2010) found that this species has great potential for the removal of nutrients and heavy metals. MoroyoquiRojo et al. (2012) studied the nutrient removal capacity of Laguncularia racemosa and Rhizophora mangle in shrimp culture ponds and found that both species presented similar nutrient removal rates. De-León-Herrera et al. (2015) measured the removal of inorganic nutrients derived from a population of Dormitator latifrons in a closed system containing Avicennia germinans, L. racemosa, and $R$. mangle, and reported that all three mangrove species can be used to remove nitrogen and phosphorus compounds.

Most studies have focused on wastewater treatment using $K$. candel that grows at tropical latitudes. In the case of the three mangrove species (A. germinans, L. racemosa, and $R$. mangle) typical of the American continent (subtropical latitudes), Moroyoqui-Rojo et al. (2012) and De-León-Herrera et al. (2015) examined nutrient removal in closed tanks without a biological filter (e.g., gravel and sand). The objective of the present study was to study the removal of fish-derived inorganic nutrients (ammonium, nitrite, nitrate, and phosphate) in tanks with periodic recirculation containing a importante en la remoción de nutrientes. Los procesos de transformación de compuestos nitrogenados en el suelo de los humedales incluyen la amonificación seguida de la nitrificación y desnitrificación (Maltais-Landry et al. 2009, Buhmann y Papenbrock 2013). En los sedimentos de los humedales, el $80-90 \%$ del fósforo se encuentra en forma orgánica, otra parte es incorporada a las plantas y una pequeña parte se encuentra en forma de ortofosfatos (Buhmann y Papenbrock 2013).

Los humedales de mangle son uno de los ecosistemas costeros más productivos en las regiones tropicales y subtropicales (Kristensen et al. 2008). Los mangles son considerados como un grupo de plantas tolerantes a los efluentes de las granjas acuícolas debido a su demanda enorme de nutrientes (Yang et al. 2008, Huang et al. 2012, Bao et al. 2013). Particularmente, estas plantas juegan un rol crítico en la remoción y degradación de contaminantes como metales pesados, pesticidas y compuestos nitrogenados y fosfatados (Kristensen et al. 2008, Reef et al. 2010, Adame y Lovelock 2011, Bayen 2012). Por lo tanto, el uso de los manglares ha sido considerado como un método relativamente simple y de bajo costo para el tratamiento de aguas provenientes de sistemas de cultivo (Ye et al. 2001, Huang et al. 2012, De-LeónHerrera et al. 2015).

En décadas recientes se han utilizado a los mangles para la remoción de compuestos nitrogenados y fosfatados. Por ejemplo, Wong et al. (1997) evaluaron la tasa de remoción de carbono y nitrógeno orgánico en dos localidades intermareales con manglares de Kandelia candel y Aegiceras corniculatum, y sus resultados sugieren que estas dos especies de mangle presentan un gran potencial para la remoción de nutrientes. Tam y Wong (1995) midieron la tasa de retención de nutrientes y metales pesados en dos tipos de suelo de manglar y demostraron que los manglares actúan como trampas de fósforo y metales pesados pero son menos eficientes en la retención de nitrógeno. Wu et al. (2008) estudiaron el uso potencial de K. candel como tratamiento secundario de agua residual municipal e indicaron que es factible el uso de esta especie para la remoción de carbono orgánico disuelto, amonio y ortofosfatos. Yang et al. (2008) utilizaron una planta piloto con K. candel, A. corniculatum y Sonneratia caseolaris para la remoción de materia orgánica y nutrientes, y encontraron que $S$. caseolaris y A. corniculatum tuvieron una mejor eficiencia en el tratamiento de agua en comparación con K. candel. Después de examinar un humedal de Sonneratia apetala expuesto a tres niveles de concentración de agua residual, Zhang et al. (2010) indicaron que la especie tiene un gran potencial para la remoción de nutrientes y metales pesados. Moroyoqui-Rojo et al. (2012) estudiaron el uso potencial de Laguncularia racemosa y Rhizophora mangle en la remoción de nutrientes inorgánicos en estanques con camarón y encontraron que las dos especies presentaron una tasa similar de remoción de nutrientes. De-León-Herrera et al. (2015) midieron la tasa de remoción de nutrientes inorgánicos de sistemas de cultivo cerrados que contenían 
biological filter (gravel and sand) as well as L. racemosa and $R$. mangle seedlings.

\section{MATERIALS AND METHODS}

\section{Collection and monitoring of mangrove propagules and fruits}

Red mangrove ( $R$. mangle) propagules and white mangrove (L. racemosa) fruits were collected in August from Urías Lagoon, northwestern Mexico $\left(23^{\circ} 13^{\prime}-23^{\circ} 11^{\prime} \mathrm{N}\right.$, $\left.106^{\circ} 23^{\prime}-106^{\circ} 21^{\prime} \mathrm{W}\right)$. All the samples were transported in plastic boxes to the Coastal Ecosystem Laboratory of the Institute of Marine Sciences and Limnology (UNAM) at Mazatlán (Mexico). The red mangrove propagules were placed in plastic buckets containing freshwater for one month for the optimum development of the root system. The white mangrove fruits were sown in polyurethane trays $(68 \times 34 \mathrm{~cm})$ using a mixture of dolomite and vermiculite as substrate (Sunshine Mix \#3). After one month (i.e., September), the seedlings of both species were transported to a tank in which salinity was raised by 10 (practical salinity scale) every month until reaching a concentration of 35-40 in December. In this tank, all seedlings were arranged in a hydroponic wooden frame. In January, all the seedlings were transported to the experimental tanks. The height of both species was measured monthly until August (i.e., seven months). All seedlings were measured with a 1-m-long flexible ruler. The red mangrove seedlings were measured from the first growth ring to the apical part of the main shoot. The white mangrove seedlings were measured from the base of the shoot to the apical part of the main shoot.

\section{Collection of poeciliid fishes}

Poeciliid fishes (Poeciliidae) were collected in December from the mangrove area within Urías Lagoon with a spoon net $(0.5 \mathrm{~cm}$ mesh size $)$. The individuals were transported in plastic containers $(100 \times 35 \mathrm{~cm})$ and placed in a 450 -L tank with salinity of 35 . They were offered a balanced commercial feed once a day at a rate of $2.56 \mathrm{~g}$ per day. In January, the individuals were placed in the experimental tanks and the length of all specimens was measured monthly until the end of the experiment (i.e., seven months) using a standardized biometric ruler for fishes.

\section{Design and construction of the experimental systems}

Six recirculating water systems were constructed (fig. 1). Each system consisted of two 450-L polyvinyl tanks (Polyplas). One tank contained 150 poeciliid fishes and the other tank contained a biological filter consisting of a 14-cm layer of gravel $(\theta=5 \mathrm{~mm})$ and a $14-\mathrm{cm}$ layer of sand. Two of the six tanks with the biological filter did not contain mangrove seedlings (i.e., control treatment). The other four una población de Dormitator latifrons y tres especies de mangle (Avicennia germinans, L. racemosa y R. mangle), y sugirieron que las tres especies de mangle pueden ser utilizadas para la óptima remoción de compuestos nitrogenados y fosfatados.

Varios estudios se han centrado en el tratamiento de agua con K. candel, que es de latitudes tropicales. MoroyoquiRojo et al. (2012) y De-León-Herrera et al. (2015) investigaron la remoción de nutrientes con las tres especies de mangle (A. germinans, L. racemosa, and $R$. mangle) típicas de latitudes subtropicales en el continente americano, pero en tanques cerrados sin filtro biológico (e.g., grava y arena). Por tal motivo, el objetivo de este trabajo fue investigar la remoción de nutrientes inorgánicos (amonio, nitrito, nitrato y fosfato) provenientes de peces poecílidos por medio de filtros biológicos de grava y arena, y plántulas de L. racemosa y $R$. mangle en tanques con recirculación periódica.

\section{MATERIALES Y MÉTODOS}

\section{Recolecta y monitoreo de los propágulos y frutas de mangle}

Durante agosto, se recolectaron propágulos de mangle rojo (R. mangle) y frutas de mangle blanco (L. racemosa) en la laguna costera del estero de Urías, noroeste de México $\left(23^{\circ} 13^{\prime}-23^{\circ} 11^{\prime} \mathrm{N}, 106^{\circ} 23^{\prime}-106^{\circ} 21^{\prime} \mathrm{W}\right)$. Todas las muestras fueron transportadas en cajas de plástico al Laboratorio de Conservación y Restauración de Ecosistemas Costeros del Instituto de Ciencias del Mar y Limnología (UNAM), unidad Mazatlán (México). Los propágulos de mangle rojo fueron depositados en cubetas de plástico con agua dulce durante un mes para el desarrollo óptimo del sistema radicular. Las frutas de mangle blanco fueron sembradas en charolas de poliuretano $(68 \times 34 \mathrm{~cm})$ utilizando como sustrato una mezcla de dolomita y vermiculita (Sunshine Mix \#3). Después de un mes (i.e., septiembre), las plántulas de ambas especies fueron transportadas a un tanque de agua en donde se realizaron incrementos de 10 de salinidad por mes hasta alcanzar una concentración de 35-40 en diciembre. En este tanque de agua, todas las plántulas fueron arregladas en forma hidropónica sobre una base de madera. A partir de enero, todas las plántulas fueron transportadas a los tanques experimentales. La medición de la altura de ambas especies se realizó mensualmente hasta agosto (i.e., siete meses). Todas las plántulas fueron medidas con una regla flexible de $1 \mathrm{~m}$ de largo. Para las muestras de mangle rojo, se tomó la medida desde el primer anillo de crecimiento hasta la parte apical del tallo principal. Para las plántulas de mangle blanco, la medida se tomó desde la base del tallo hasta la parte apical del tallo principal.

\section{Recolecta de los peces poecílidos}

Los peces poecílidos (Poeciliidae) fueron recolectados durante diciembre en la zona de manglar dentro del estero de 

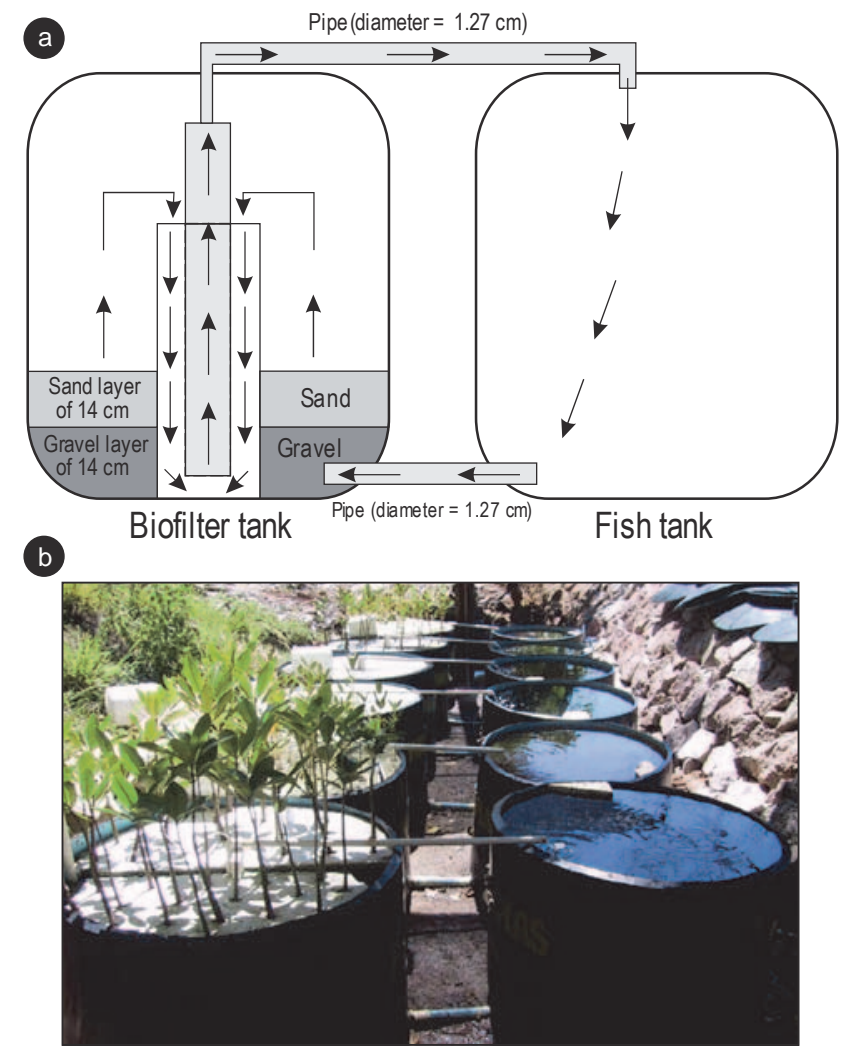

Figure 1. Diagram (a) and photograph (b) of the water recirculating systems. The six tanks on the right-hand side held poeciliid fishes. The six tanks on the left contained a biological filter and either Laguncularia racemosa or Rhizophora mangle seedlings or no mangrove seedlings (i.e., control treatment). The black arrows indicate the direction of water circulation.

Figura 1. Esquema (a) y fotografía (b) de los sistemas de recirculación de agua. Los seis tanques de la derecha contenían a los peces poecílidos y los seis de la izquierda contenían el filtro biológico ya sea con plántulas de Laguncularia racemosa o Rhizophora mangle, o sin plántulas (i.e., control). Las flechas negras indican el sentido de circulación del agua.

contained an arrangement of 34 seedlings on a floating 1-cmthick polyurethane sheet. Two of them contained red mangrove seedlings and two contained white mangrove seedlings. Salinity in the tanks was kept at 35.

The two tanks of each system were connected by two plastic pipes ( $1.27 \mathrm{~cm}$ in diameter), one at the top and one at the bottom, through which the water exchange occurred (fig. 1). Three Elite-802 air pumps $(115 \mathrm{~V})$ were used to circulate the water between the tanks. There were two air ducts in the tank containing the biological filter. Each duct supplied air to a recirculating system via a hose $(0.64 \mathrm{~cm}$ in diameter) that reached the middle section of the system. The water flowed from the bottom of the fish tank into the bottom of the seedling tank, where it circulated vertically through the sand and gravel biofilter to the middle section of the tank. A 10.16-cm-diameter PVC tube was installed in the center of the biofilter, which in turn contained another PVC tube (1.91 $\mathrm{cm}$ in diameter) that was connected to a horizontal tube (1.27 $\mathrm{cm}$ in diameter) through which the water returned to the fish tank.
Urías con una red tipo cuchara (luz de malla de $0.5 \mathrm{~cm}$ ). Los organismos fueron transportados en recipientes de plástico de $100 \times 35 \mathrm{~cm}$ y posteriormente confinados en un tanque de $450 \mathrm{~L}$ con salinidad de 35 . Los organismos fueron alimentados una vez al día con un compuesto comercial balanceado a una tasa de $2.56 \mathrm{~g}$ por día. En enero, los peces fueron distribuidos en los tanques experimentales, y se midió la longitud de todos los peces mensualmente hasta el final del experimento (i.e., siete meses) con una regla biométrica estandarizada para peces.

\section{Diseño y construcción de los sistemas experimentales}

Se construyeron seis sistemas de recirculación vertical de agua con una salinidad de 35. Cada sistema estaba constituido por dos tanques de polivinilo (Polyplas) de $450 \mathrm{~L}$ (fig. 1). En el primer arreglo de tanques se confinaron 150 peces poecílidos por tanque, mientras que el segundo arreglo de tanques contenía un filtro biológico conformado por una capa de $14 \mathrm{~cm}$ de grava $(\theta=5 \mathrm{~mm})$ y $14 \mathrm{~cm}$ de arena. De los 


\section{Water-quality sampling and nutrient measurements}

Samples to analyze water quality in the tanks were taken from January to August. The fish were fasted for $24 \mathrm{~h}$ prior to taking the water samples so that the food would not influence the nutrient measurements. The water exchanges between tanks were performed every 10 days over a 24 -h period, during which four samples were taken. The first sample was taken before initiating the water exchange $(0 \mathrm{~h})$, the second sample was taken after $8 \mathrm{~h}$ (first recirculation), the third sample after $16 \mathrm{~h}$ (second recirculation), and the fourth sample after $24 \mathrm{~h}$ (third recirculation). The monthly values were then grouped by seasons: winter (January to March), spring (April to June), and summer (July to August). Duplicate water samples (i.e., pseudo-replicates) were taken in 125 -mL plastic bottles from each tank containing the biofilter. All samples were analyzed for ammonium, nitrite, nitrate, and phosphate content using the spectrophotometric techniques described by Strickland and Parsons (1972). Water temperature and salinity were measured weekly with a thermometer (Brannan) and a refractometer (Atago \#80-124), respectively. The efficiency of nutrient removal in the experimental system was calculated using the equation described by Paniagua-Michel and García (2003):

$$
\mathrm{R}=((\mathrm{E}-\mathrm{S}) / \mathrm{E}) 100
$$

where $\mathrm{R}$ is the percent nutrient removal, $\mathrm{E}$ is the mean concentration of nutrients at the beginning of the recirculation period (i.e., $0 \mathrm{~h}$ ), and $\mathrm{S}$ is the mean concentration of nutrients at the end of the period (i.e., $24 \mathrm{~h}$ ).

\section{Statistical analysis}

The growth of mangrove seedlings was analyzed by linear regressions. The linear association between seedling height and time was examined using the coefficient of determination $\left(R^{2}\right)$ and analysis of variance. The Kruskal-Wallis nonparametric test was used to analyze differences in seedling growth as well as differences in temperature, salinity, and nutrient content between the control and mangrove treatments. The growth of the poeciliid fishes in the six tanks was analyzed by logarithmic regressions.

\section{RESULTS}

\section{Growth of mangrove seedlings and poeciliid fishes}

There was a significant difference $(P<0.05)$ in seedling growth between treatments (fig. 2a), with $L$. racemosa showing a greater slope $(1.85 \mathrm{~cm} /$ month $)$ than $R$. mangle $(0.85 \mathrm{~cm} /$ month $)$. There were no significant differences $(P>$ 0.05 ) in fish length between treatments (fig. 2b). seis tanques con filtro biológico, dos no contenían plántulas (i.e., control) y los cuatro restantes contenían un arreglo de 34 plántulas de mangle rojo o blanco (dos réplicas por especie) flotando sobre láminas perforadas de poliuretano de $1 \mathrm{~cm}$ de espesor.

Los tanques de cada sistema estaban conectados por dos tubos de plástico ( $1.27 \mathrm{~cm}$ de diámetro), uno en la parte superior y otro en la parte inferior, por donde se llevó a cabo el intercambio de agua (fig. 1). Para que el agua circulara entre ambos tanques, se utilizaron tres bombas de aire (Elite 802, $115 \mathrm{~V})$ con dos salidas de aire hacia el tanque con filtro biológico. Cada salida suministraba aire a un sistema de recirculación por medio de una manguera $(0.64 \mathrm{~cm}$ de diámetro) que llegaba hasta la parte media del sistema. El agua fluía de la parte inferior del tanque de los peces hacia la parte inferior del tanque de las plántulas. Una vez en el tanque de las plántulas, el agua circulaba en forma vertical por el biofiltro de arena y grava hasta la parte media del tanque. En el centro del biofiltro se colocó un tubo de PVC de $10.16 \mathrm{~cm}$ de diámetro y dentro del mismo se instaló otro tubo de PVC, pero de $1.91 \mathrm{~cm}$ de diámetro, conectado a un tubo horizontal ( $1.27 \mathrm{~cm}$ de diámetro) por donde el agua regresaba al tanque de los peces.

\section{Toma de muestras de agua y medición de nutrientes}

La toma de muestras para analizar la calidad del agua de los tanques se realizó de enero a agosto. Antes de cada toma de muestra de agua, se mantuvieron a los peces en ayuno por un periodo de $24 \mathrm{~h}$ para evitar que el alimento influyera en la medición de nutrientes. La recirculación de agua entre ambos tanques se realizó cada 10 días durante $24 \mathrm{~h}$. Dentro de este periodo de tiempo, se realizaron cuatro muestreos de agua. El primer muestreo se realizó antes de iniciar la recirculación de agua $(0 \mathrm{~h})$, el segundo se hizo al pasar las primeras $8 \mathrm{~h}$ (primera recirculación), el tercero después de $16 \mathrm{~h}$ (segunda recirculación) y el cuarto depués de $24 \mathrm{~h}$ (tercera recirculación). Se agruparon los valores mensuales en tres temporadas: invierno (enero a marzo), primavera (abril a junio) y verano (julio a agosto). Las muestras de agua fueron tomadas por duplicado (i.e., pseudoréplicas) en botellas de plástico de $125 \mathrm{~mL}$ de cada uno de los tanques con biofiltro. Para cada muestra, se analizó el contenido de amonio, nitrito, nitrato y fosfatos mediante las técnicas espectrofotométricas descritas por Strickland y Parsons (1972). Además, semanalmente se midió la temperatura del agua con un termómetro (Brannan) y la salinidad con un refractómetro (Atago \#80-124). Para calcular la efíciencia en la remoción de nutrientes en el sistema experimental, se utilizó la ecuación descrita por Paniagua-Michel y García (2003):

$$
\mathrm{R}=((\mathrm{E}-\mathrm{S}) / \mathrm{E}) 100
$$

donde $\mathrm{R}$ corresponde al porcentaje de remoción, $\mathrm{E}$ es la concentración promedio de nutrientes al inicio de la 

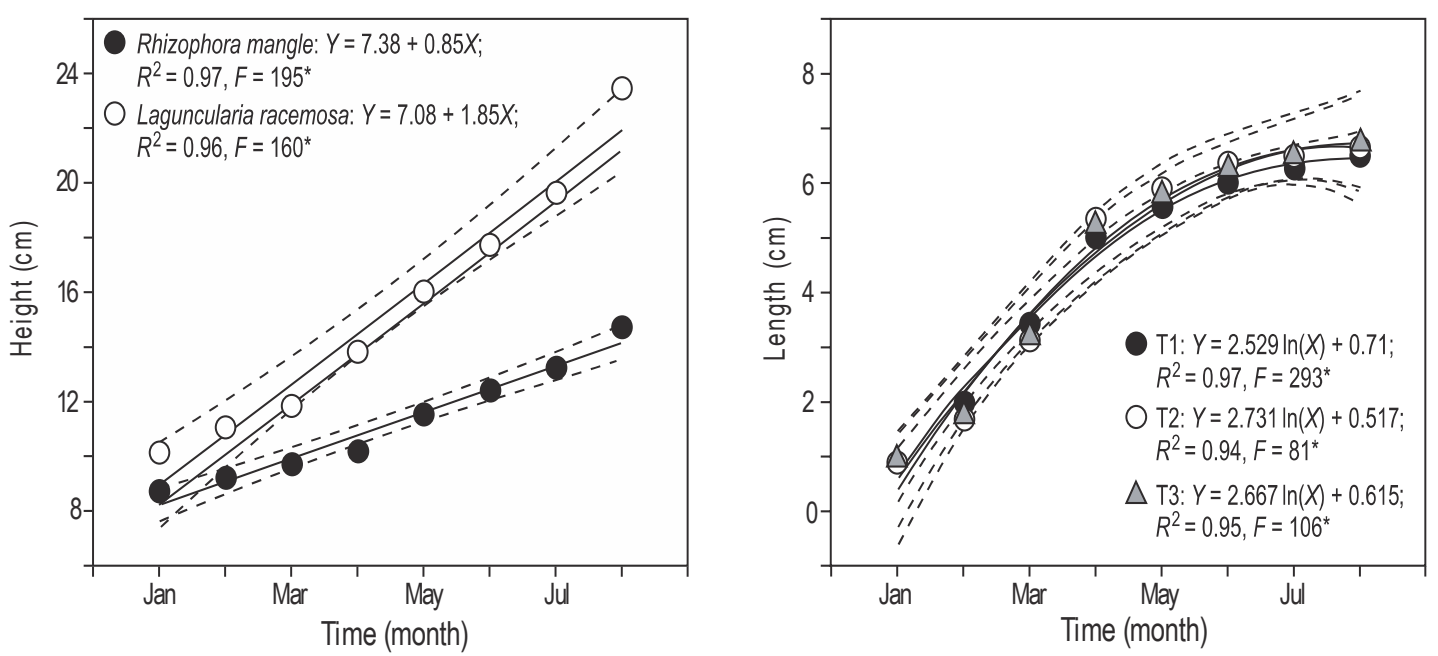

Figure 2. Mangrove seedling height (a) and poeciliid fish growth (b) from January to August. T1 represents the Rhizophora mangle treatment, T2 the Laguncularia racemosa treatment, and T3 the control treatment. Each plot shows the linear or logarithmic equation, the coefficient of determination $\left(R^{2}\right)$, and the $F$-test value. Asterisks indicate significant $F$ values at $\alpha=0.05$. Sixty-eight seedlings and 300 fish were measured monthly per treatment.

Figura 2. Altura de las plántulas de mangle (a) y longitud de los peces poecílidos (b) de enero a agosto. T1 representa el sistema con Rhizophora mangle, T2 representa el sistema con Laguncularia racemosa y T3 representa el control. Cada gráfica muestra la ecuación lineal o logarítmica, el coeficiente de determinación $\left(R^{2}\right)$ y el valor de la prueba $F$. Los asteriscos indican valores significativos de la prueba $F$ a $\alpha=$ 0.05. El número de plántulas medidas mensualmente fue de 68 por tratamiento, y la muestra de peces fue de 300 por tratamiento.

\section{Physical and chemical properties of water and nutrient content}

Water temperature in the experimental tanks was $24.5^{\circ} \mathrm{C}$ in January, February, and March, and ranged from 35 to $37^{\circ} \mathrm{C}$ between April and August (fig. 3a). There were no significant differences $(P>0.05)$ in water temperature between treatments. Salinity was higher in January, July, and August $(\sim 35)$, and lowest in March ( 27), but no significant differences $(P>0.05)$ were observed between treatments (fig. $3 b)$.

There were significant differences in the percent removal and temporal variability (January to August) of dissolved inorganic nitrogen $\left(\mathrm{NH}_{4}^{+}, \mathrm{NO}_{2}^{-}\right.$, and $\left.\mathrm{NO}_{3}^{-}\right)$in the three treatments during the 24-h recirculation period (fig. 4). During the first three months (i.e., winter), dissolved inorganic nitrogen removal in the control treatment was very low $(32 \pm 10 \%)$ relative to the treatments using $L$. racemosa $(78 \pm 10 \%)$ and R. mangle (75 $\pm 7 \%$ ) (fig. $4 \mathrm{a})$. In spring, it decreased in the control treatment $(29 \pm 8 \%)$ as well as in the $R$. mangle treatment $(70 \pm 15 \%)$, but increased in the $L$. racemosa treatment ( $82 \pm 10 \%)$ (fig. $4 b)$. During the last two months of the experiment (i.e., summer), it increased to $42 \pm 8 \%$ in the control treatment, but increased considerably in the L. racemosa and $R$. mangle treatments to $90 \pm 13 \%$ and $90 \pm 11 \%$, respectively (fig. 4c).

Significant differences were observed in the percent removal of dissolved inorganic phosphorus $\left(\mathrm{PO}_{4}^{-3}\right)$. In winter it was lower $(48 \pm 12 \%)$ in the control treatment than in the L. racemosa $(62 \pm 18 \%)$ and $R$. mangle $(55 \pm 21 \%)$ recirculación (i.e., 0 h) y S es la concentración promedio de nutrientes al final de la recirculación (i.e., 24 h).

\section{Análisis estadístico}

El crecimiento de las plántulas de mangle fue analizado mediante regresiones lineales. Se utilizó el coeficiente de determinación $\left(R^{2}\right)$ y análisis de varianza para examinar la asociación lineal entre la altura de las plántulas y el periodo de tiempo. Se utilizó la prueba no paramétrica de Kruskal-Wallis para evaluar la diferencia en el crecimiento de las plántulas así como la diferencia en los valores de temperatura, salinidad y contenido de nutrientes entre los tanques que contenían mangles y los tanques de control. El crecimiento de los peces poecílidos en los seis sistemas de recirculación fue evaluada por medio de regresiones logarítmicas.

\section{RESUlTADOS}

\section{Crecimiento de las plántulas de mangle y los peces poecílidos}

Se registró una diferencia significativa $(P<0.05)$ en el crecimiento de las plántulas de mangle entre los tanques experimentales. En particular, L. racemosa mostró una mayor pendiente $(1.85 \mathrm{~cm}$ por mes) en comparación con las plántulas de $R$. mangle $(0.85 \mathrm{~cm}$ por mes) (fig. $2 \mathrm{a})$. No se observaron diferencias significativas $(P>0.05)$ en la longitud de los peces entre los tratamientos (fig. $2 b$ ). 

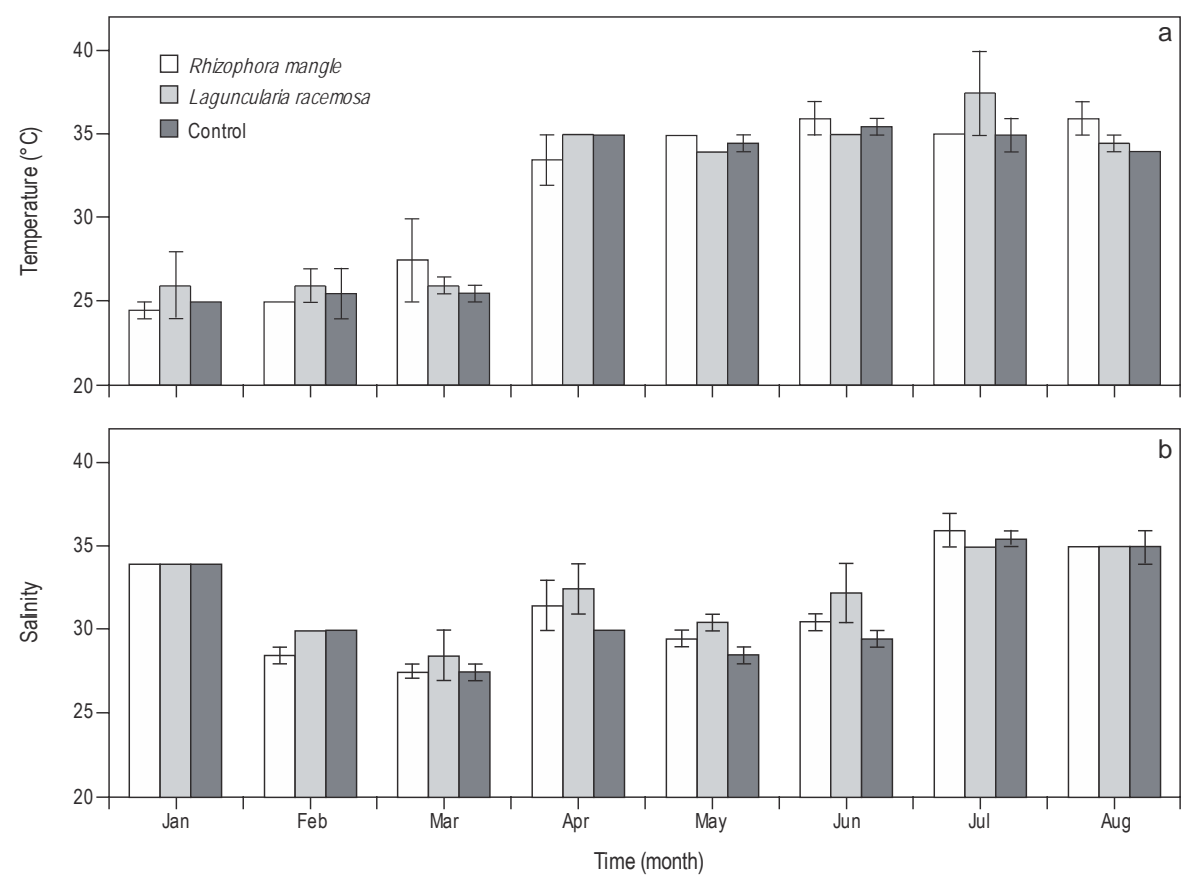

Figure 3. Time series of water temperature and salinity in the control, Laguncularia racemosa, and Rhizophora mangle treatments. Error bars represent one standard deviation. Eight temperature and salinity measurements were taken monthly per treatment.

Figura 3. Serie de tiempo para la temperatura del agua y salinidad en los sistemas de control, con Laguncularia racemosa y con Rhizophora mangle. Las barras de error representan la primera desviación estándar. El número de mediciones de la temperatura y salinidad por tratamiento fue de ocho por mes.

treatments (fig. 5a). In spring it decreased slightly in all three treatments, to $45 \pm 16 \%$ in the control treatment, $41 \pm 24 \%$ in the $L$. racemosa treatment, and $53 \pm 25 \%$ in the $R$. mangle treatment (fig. 5b). In summer it remained similar in the control treatment $(45 \pm 14 \%)$, but increased to $44 \pm 37 \%$ in the L. racemosa treatment and decreased to $35 \pm 39 \%$ in the R. mangle treatment (fig. 5c).

\section{DISCUSSION}

In view of the constant expansion of aquaculture activities, it is necessary to understand to what extent mangrove wetlands can be used as biofilters to reduce the eutrophic conditions in culture ponds. In this study we examined the removal of nutrients $\left(\mathrm{NH}_{4}^{+}, \mathrm{NO}_{2}^{-}, \mathrm{NO}_{3}^{-}\right.$, and $\left.\mathrm{PO}_{4}^{-3}\right)$ in closed recirculating systems by two mangrove species typical of semi-arid areas of Mexico.

The linear growth of the mangrove seedlings indicated the removal of dissolved inorganic nutrients (nitrogen and phosphorus) in the experimental tanks. Nitrogen removal rates increase according to plant biomass and coverage (Tanner et al. 1995, Yang et al. 2008, De-León-Herrera et al. 2015). The nitrogen cycle in wetlands is complex and is discussed in detail by Reed et al. (1995). In our experiment, largest nitrogen loss occurred because of denitrification. Denitrification is a form of anaerobic respiration by certain

\section{Propiedades fisicoquímicas del agua y contenido de nutrientes}

La temperatura del agua en los tanques experimentales fue de $24.5^{\circ} \mathrm{C}$ de enero a marzo y osciló entre 35 y $37^{\circ} \mathrm{C}$ de abril a agosto (fig. 3a). La temperatura del agua no presentó diferencia significativa $(P>0.05)$ entre los tres tratamientos. La salinidad presentó las mayores concentraciones en enero, julio y agosto $(\sim 35)$, y la menor concentración ocurrió en marzo ( 27). Sin embargo, no se presentaron diferencias significativas $(P>0.05)$ entre los tres tratamientos (fig. 3b).

Se observaron diferencias significativas en el porcentaje de remoción y la variabilidad temporal (enero a agosto) del nitrógeno inorgánico disuelto $\left(\mathrm{NH}_{4}^{+}, \mathrm{NO}_{2}^{-}\right.$y NO$\left.{ }_{3}^{-}\right)$en los tres tratamientos durante el periodo de $24 \mathrm{~h}$ de recirculación de agua (fig. 4). Durante los primeros tres meses de muestreo (i.e., invierno), el porcentaje de remoción en el tratamiento de control fue muy bajo (32 $\pm 10 \%)$ en comparación con los tratamientos con $L$. racemosa $(78 \pm 10 \%)$ y $R$. mangle $(75 \pm 7 \%$ ) (fig. $4 a)$. Durante la primavera, el porcentaje disminuyó en los tratamientos de control $(29 \pm 8 \%)$ y en los tratamientos con $R$. mangle ( $70 \pm 15 \%$ ), pero aumentó en los tratamientos con L. racemosa ( $82 \pm 10 \%$ ) (fig. $4 \mathrm{~b})$. Durante los últimos dos meses del experimento (i.e., verano), el porcentaje final de remoción en los tratamientos de control aumentó a $42 \pm 8 \%$, pero aumentó considerablemente en los 


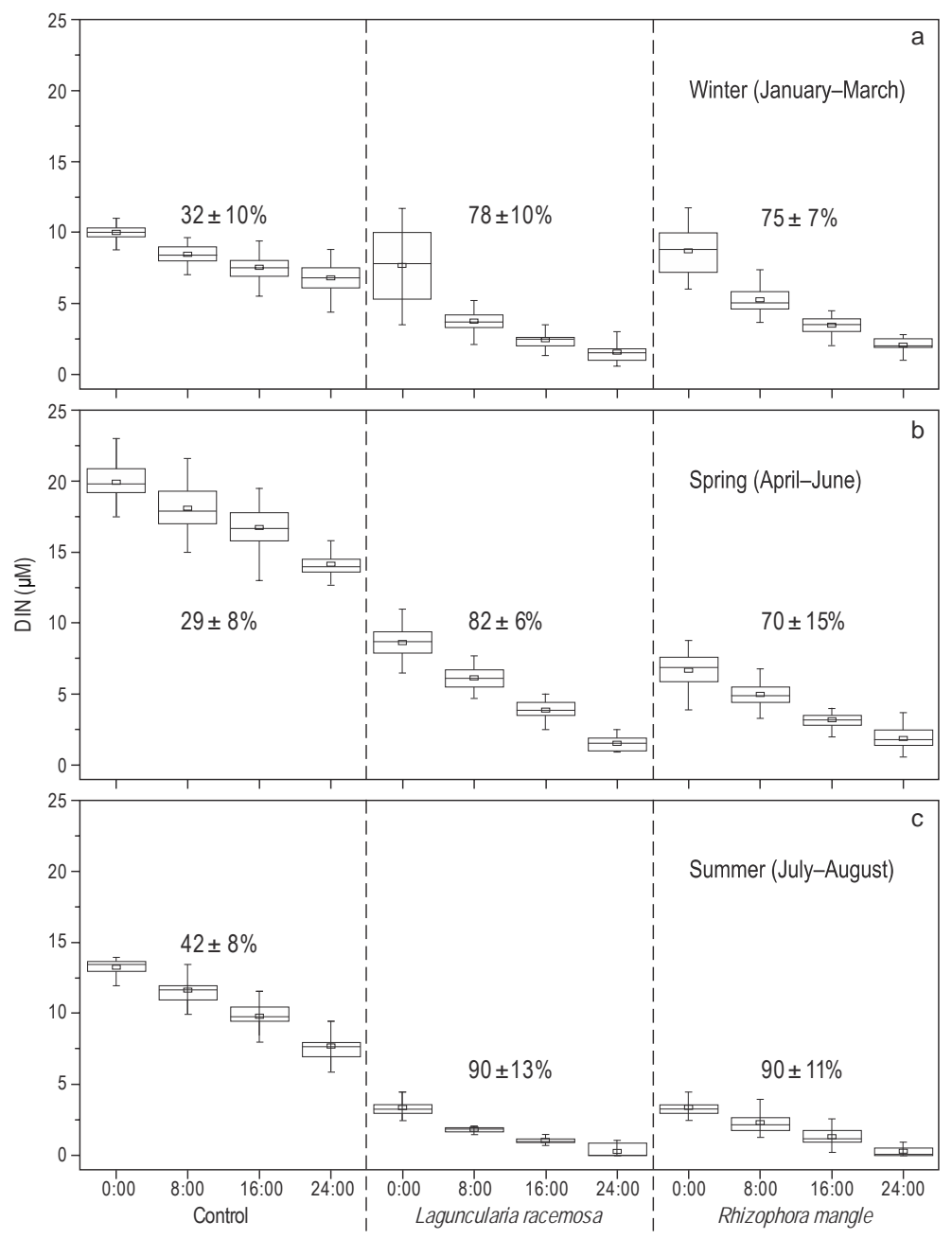

Figure 4. Percent removal (mean and standard deviation) and temporal variability in winter (a), spring (b), and summer (c) of dissolved inorganic nitrogen (DIN: $\mathrm{NH}_{4}^{+}, \mathrm{NO}_{2}^{-}$, and $\mathrm{NO}_{3}^{-}$) in the three treatments during the 24-h water recirculation periods. Each box diagram depicts the mean (small box), minimum sample, lower quartile (lower part of the box), median (middle part of the box), upper quartile (upper part of the box), and maximum sample. The total number of monthly samples per nutrient was 24 .

Figura 4. Porcentaje de remoción (promedio y desviación estándar) y variabilidad temporal durante el invierno (a), primavera (b) y verano (c) del nitrógeno inorgánico disuelto (DIN: $\mathrm{NH}_{4}{ }^{+}, \mathrm{NO}_{2}^{-} \mathrm{y} \mathrm{NO}_{3}^{-}$) en los tres tratamientos durante los periodos de 24 h de recirculación de agua. Cada diagrama de caja muestra la media (cuadro pequeño), la muestra mínima, el cuartil menor (parte inferior de la caja), la mediana (parte media de la caja), el cuartil mayor (parte superior de la caja) y la muestra máxima. El número total de muestras mensuales por nutriente fue de 24.

bacteria, whereby nitrate (or nitrite) is used as the terminal electron acceptor for the oxidation of organic compounds and is reduced to gaseous products such as $\mathrm{N}_{2} \mathrm{O}$ and $\mathrm{N}_{2}$ (Gersberg et al. 1983). However, the formation of intermediate products during nitrification and denitrification is not fully understood (Tam et al. 2009). In general, nitrates can be removed through denitrification and plant uptake. Mangrove seedlings not only absorb nitrate for their growth, but also improve the efficiency of the nitrification and denitrification processes (Wu et al. 2008). Our results indicate that the growth of the $L$. racemosa and $R$. mangle seedlings was associated with the absorption of nitrogen and phosphorus from the metabolic residues of the poeciliid fishes and the excess food. tratamientos con L. racemosa $(90 \pm 13 \%)$ y $R$. mangle $(90 \pm$ $11 \%$ ) (fig. 4c).

Se observaron diferencias significativas en el porcentaje de remoción de fósforo inorgánico disuelto $\left(\mathrm{PO}_{4}^{-3}\right)$ (fig. 5). En invierno, el porcentaje fue menor en los tratamientos de control (48 $\pm 12 \%$ ) en comparación con los tratamientos que contenían $L$. racemosa $(62 \pm 18 \%)$ y $R$. mangle $(55 \pm 21 \%)$ (fig. 5a). Los porcentajes disminuyeron ligeramente en los tres tratamientos durante la primavera, cuando los valores fueron $45 \pm 16 \%, 41 \pm 24 \%$ y $53 \pm 25 \%$ para los tratamientos de control, los tratamientos con L. racemosa y los tratamientos con $R$. mangle, respectivamente (fig. 5b). En verano, el porcentaje de remoción en los tratamientos de control se 


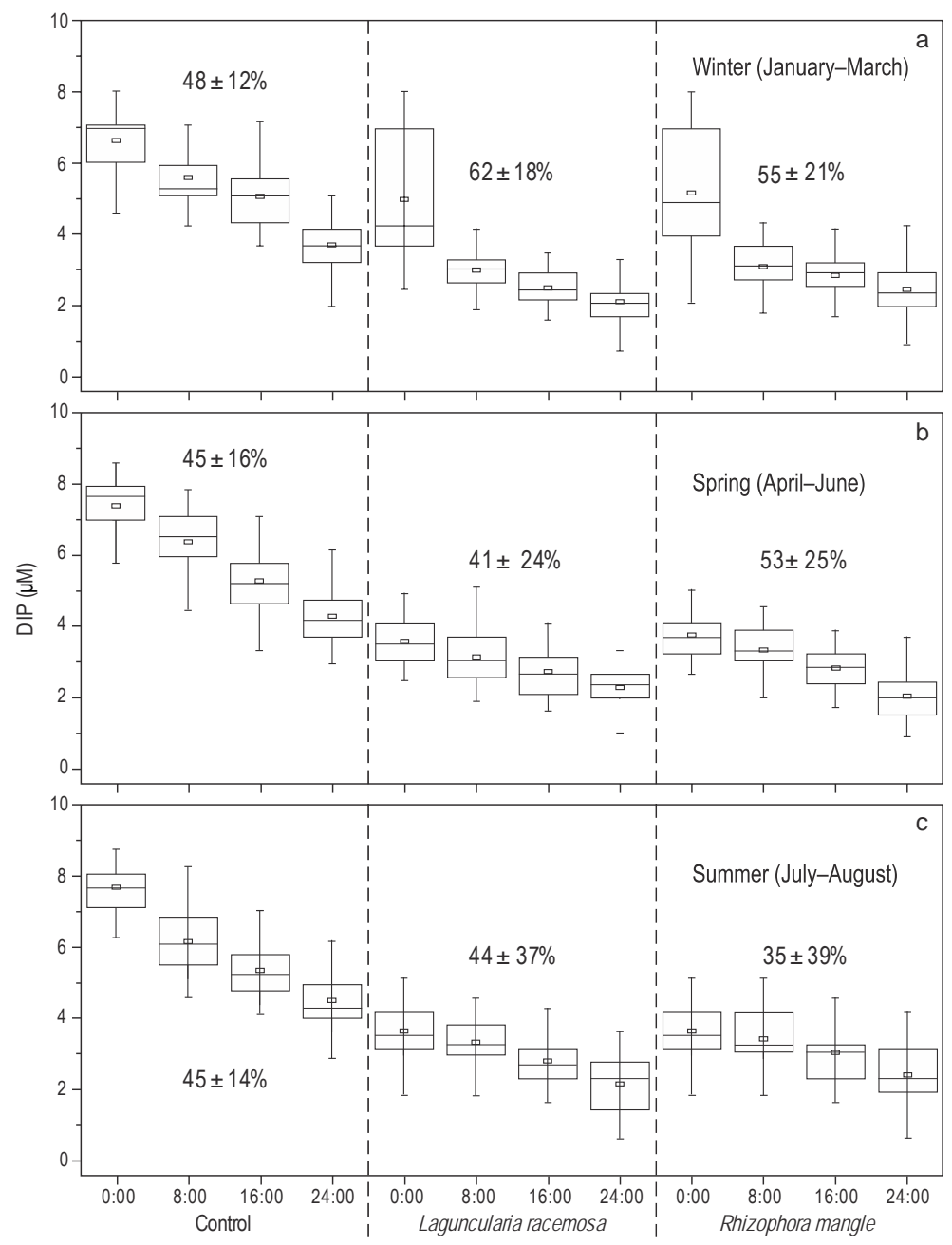

Figure 5. Percent removal (mean and standard deviation) and temporal variability in winter (a), spring (b), and summer (c) of dissolved inorganic phosphorus (DIP: $\mathrm{PO}_{4}^{-3}$ ) in the three treatments during the 24-h water recirculation periods. Each box diagram depicts the mean (small box), minimum sample, lower quartile (lower part of the box), median (middle part of the box), upper quartile (upper part of the box), and maximum sample. The total number of monthly samples was 24 .

Figura 5. Porcentaje de remoción (promedio y desviación estándar) y variabilidad temporal durante el invierno (a), primavera (b) y verano (c) del fósforo inorgánico disuelto (DIP: $\mathrm{PO}_{4}^{-3}$ ) en los tres tratamientos durante los periodos de 24 h de recirculación de agua. Cada diagrama de caja muestra la media (cuadro pequeño), la muestra mínima, el cuartil menor (parte inferior de la caja), la mediana (parte media de la caja), el cuartil mayor (parte superior de la caja) y la muestra máxima. El número total de muestras mensuales fue de 24.

Mangrove growth rates depend on the nutrients in the system (Saenger 2002); however, L. racemosa seedlings present a more rapid increase in height relative to $R$. mangle under a variety of experimental conditions (e.g., CardonaOlarte et al. 2006, Krauss et al. 2006, Moroyoqui-Rojo et al. 2012, Monroy-Torres et al. 2014, De-León-Herrera et al. 2015). In the present study, the mangrove seedlings showed this same growth pattern, but our results indicate that there were no differences in nutrient removal between both species. This suggests that $L$. racemosa and $R$. mangle have different metabolic adaptations depending on the concentration of nutrients. We suggest that the difference in height increase mantuvo similar ( $45 \pm 14 \%)$, mientras que en los tratamientos con L. racemosa aumentó a $44 \pm 37 \%$ y en los tratamientos con R. mangle disminuyó a $35 \pm 39 \%$ (fig. $5 \mathrm{c}$ ).

\section{Discusión}

Debido a la constante expansión de las actividades relacionadas con la acuacultura, es necesario entender hasta qué grado los mangles pueden ser utilizados como biofiltro para la reducción de la eutrofización típica de las pozas de acuacultura. En este estudio, se analizaron los porcentajes de remoción de nutrientes $\left(\mathrm{NH}_{4}^{+}, \mathrm{NO}_{2}^{-}, \mathrm{NO}_{3}^{-} \mathrm{y} \mathrm{PO}_{4}^{-3}\right)$ en 
but similar nutrient uptake of both species is attributable to their typical morphological patterns. For example, the nutrients assimilated by $R$. mangle seedlings can be used to develop new leaves, which are larger than those of $L$. racemosa (Flores-de-Santiago et al. 2012). Also, the stem density of $R$. mangle seedlings is greater than that of $L$. racemosa (Flores-Verdugo et al. 1990). One advantage of this difference in growth is that $R$. mangle could be used in bioremediation processes that are restricted by the physical dimensions of the culture systems such as in our experiment, whereas in large culture areas (e.g., farms) L. racemosa could be used because of its rapid growth.

Another problem that can limit the removal of nitrogen compounds is oxygen insufficiency. Oxygen is needed to accelerate the mineralization process and is essential for the nitrification process (Bowmer 1987). Unlike closed systems with no oxygenation (e.g., De-León-Herrera et al. 2015), our experimental design had two air pumps and a gravel and sand filter. We believe that $90 \%$ nitrogen removal was obtained as a result of the increase in oxygen level and presence of the filter. Microalgae were observed in all the culture systems during the experiment. These microalgae, typical of subtropical climates, can affect the nutrient removal measurements because they require inorganic nutrients in order to grow. Despite the presence of microalgae in all the systems, the difference in nutrient removal between the control and mangrove treatments is clear and we do not believe that they greatly affected the results obtained in this study. Moreover, the variability in temperature and salinity was not a limiting factor for nutrient removal and fish growth since there were no differences among the three treatments.

The uptake of phosphate compounds by wetlands involves several pathways and is considered a complex biogeochemical cycle. The main removal mechanisms include the sedimentation of phosphorus-containing particles, the adsorption of soluble phosphorus onto clay particles, and phosphate assimilation by aquatic macrophytes (Greenway and Woolley 1999). Even though the concentrations of phosphate are lower than those of nitrogen compounds in aquaculture ponds, it is considered a limiting nutrient in mangrove forests (Ye et al. 2001), and uptake by mangrove plants could be a major phosphate removal mechanism (Greenway and Woolley 1999).

While several studies have demonstrated the use of mangroves to reduce nutrients in coastal environments (e.g., Wong et al. 1997, Chu et al. 1998, Boonsong et al. 2003), few have compared different mangrove species (Ye et al. 2001, Yang et al. 2008), particularly in semi-arid areas. Nutrient removal by L. racemosa and $R$. mangle in semi-arid environments may be lower than that of tropical species such as A. corniculatum, K. candel, Bruguiera gymnorrhiza, and Rhizophora stylosa (De-León-Herrera et al. 2015); however, in our experiment using a gravel and sand filter in the experimental tanks, nitrogen removal by $L$. racemosa and $R$. mangle seedlings was $90 \%$, similar to that of tropical species tanques de recirculación cerrados por medio de dos especies de mangle típicas de las zonas semiáridas de México.

El crecimiento lineal de las plántulas de mangle fue un reflejo de la remoción de nutrientes inorgánicos disueltos (nitrógeno y fósforo) en los tanques experimentales. La tasa de remoción de nitrógeno se incrementa de acuerdo con la biomasa y el grado de cobertura de las plantas acuáticas (Tanner et al. 1995, Yang et al. 2008, De-León-Herrera et al. 2015). El ciclo del nitrógeno en humedales es complejo y es discutido en detalle por Reed et al. (1995). En particular, la mayor pérdida de nitrógeno en el sistema de experimentación fue por desnitrificación. La desnitrificación es un proceso de respiración anaerobia hecha por cierto género de bacterias, en el cual el nitrato y nitrito son usados como terminales aceptoras de electrones para la oxidación de compuestos orgánicos y son reducidos a productos gaseosos tales como $\mathrm{N}_{2} \mathrm{O}$ y $\mathrm{N}_{2}$ (Gersberg et al. 1983). Sin embargo, los procesos de formación de productos intermedios durante la nitrificación y desnitrificación en humedales no son claros (Tam et al. 2009). En general, los nitratos pueden ser removidos por el proceso de desnitrificación y la asimilación de las plantas. Las plántulas de mangle no solo absorben nitrato para su crecimiento, sino también mejoran la eficiencia en los procesos de nitrificación y desnitrificación (Wu et al. 2008). Los resultados del presente estudio indican que el crecimiento de las plántulas de $L$. racemosa y $R$. mangle se debió a la absorción del nitrógeno y fósforo derivados de los residuos metabólicos de los peces poecílidos y del exceso de alimento.

La tasa de crecimiento de los mangles depende de los nutrientes en el sistema (Saenger 2002). Sin embargo, las plántulas de $L$. racemosa presentan un incremento en altura más rápido comparadas con $R$. mangle en una variedad de condiciones experimentales (e.g., Cardona-Olarte et al. 2006, Krauss et al. 2006, Moroyoqui-Rojo et al. 2012, MonroyTorres et al. 2014, De-León-Herrera et al. 2015). Durante el experimento, las plántulas de mangle siguieron este mismo patrón de crecimiento; sin embargo, los resultados del análisis indican que no hay diferencias con respecto a la remoción de nutrientes entre las dos especies. Esto sugiere que $L$. racemosa y $R$. mangle tienen diferentes adaptaciones metabólicas dependiendo de la concentración de nutrientes que se presente. Se sugiere que una de las razones por las cuales ambas especies presentaron diferencias en el incremento de altura pero una similar incorporación de nutrientes se debe a patrones morfológicos típicos de ambas especies. Por ejemplo, los nutrientes asimilados por las plántulas de $R$. mangle pueden ser utilizados en el desarrollo de hojas nuevas, las cuales son de mayor tamaño comparadas con L. racemosa (Flores-de-Santiago et al. 2012). Adicionalmente, la densidad del tallo de las plántulas de R. mangle es mayor que la del tallo de L. racemosa (Flores-Verdugo et al. 1990). Una ventaja de esta diferencia en crecimiento pudiera ser el uso de $R$. mangle en procesos de biorremediación donde se presenten restricciones en las dimensiones físicas de los sistemas de cultivo, tales como en nuestro experimento, 
such as K. candel (92.7\%) and B. gymnorrhiza (98\%) (Ye et al. 2001, Huang et al. 2012). On the other hand, phosphorus removal by $L$. racemosa and $R$. mangle was unsatisfactory (35-44\%). Therefore, understanding the processes related to mangroves as exporters or importers of phosphate depends on the location and environmental factors that affect the biological responses.

The differences observed in the removal of dissolved nitrogen by $L$. racemosa and $R$. mangle seedlings indicate that these semi-arid species are capable of removing a considerable amount of inorganic nitrogen in tanks with water recirculation. It is, however, necessary to understand the nutrient transformation processes in the mangrove ecosystems to optimize the operational parameters, including the physical and biological design of the treatment systems.

\section{ACKNOWLEDGMENTS}

The first author received financial support from the Instituto Politécnico Nacional (Mexico). Funding for the field work was provided by the Instituto de Ciencias del Mar y Limnología, Universidad Nacional Autónoma de México (UNAM). The fourth author acknowledges financial support from UNAM (Dirección General de Asuntos del Personal Académico). We thank MN Herrera-Moreno for assistance during the laboratory analysis.

English translation by Christine Harris.

\section{REFERENCES}

Adame MF, Lovelock CE. 2011. Carbon and nutrient exchange of mangrove forests with the coastal ocean. Hydrobiologia 663(1): 23-50.

http://dx.doi.org/10.1007/s10750-010-0554-7

Asche F. 2008. Farming the sea. Mar. Resour. Econ. 23(4): 527-547.

Bao H, Wu Y, Unger D, Du J, Herbeck LS, Zhang J. 2013. Impact of the conversion of mangroves into aquaculture ponds on the sedimentary organic matter composition in a tidal flat estuary (Hainan Island, China). Cont. Shelf Res. 57: 82-91. http://dx.doi.org/10.1016/j.csr.2012.06.016

Barraza-Guardado RH, Martínez-Córdoba LR, Enríquez-Ocaña LF, Martínez-Porchas M, Miranda-Baeza A, Porchas-Cornejo MA. 2014. Effect of shrimp farm effluent on water and sediment quality parameters off the coast of Sonora, Mexico. Cienc. Mar. 40(4): 221-235.

http://dx.doi.org/10.7773/cm.v40i4.2424

Bayen S. 2012. Occurrence, bioavailability and toxic effects of trace metals and organic contaminants in mangrove ecosystems: A review. Environ. Int. 48: 84-101.

http://dx.doi.org/10.1016/j.envint.2012.07.008

Boonsong K, Piyatiratitivorakul S, Patanaponpaiboon P. 2003. Potential use of mangrove plantation as constructed wetland for municipal wastewater treatment. Water Sci. Technol. 48(5): 257-266.

Bouwman L, Beusen A, Glibert PM, Overbeek C, Pawlowski M, Herrera J, Mulsow S, Yu R, Zhou M. 2013. Mariculture: Significant and expanding cause of coastal nutrient enrichment. Environ. Res. Lett. 8(4): 044026.

http://dx.doi.org/10.1088/1748-9326/8/4/044026 mientras que en grandes extensiones de cultivo (e.g., granjas de acuacultura) se pudiera utilizar L. racemosa por su rápido crecimiento.

Un problema que puede limitar la eficiencia en la remoción de compuestos nitrogenados puede ser la insuficiencia de oxígeno. El oxígeno es requerido para acelerar la mineralización y es esencial para el proceso de nitrificación (Bowmer 1987). A diferencia de los sistemas cerrados sin oxigenación (e.g., De-León-Herrera et al. 2015), nuestro diseño experimental contaba con dos bombas de aire y un filtro de grava y arena. Se considera que el incremento en el nivel de oxígeno y el filtro biológico dieron como resultado un porcentaje de remoción de nitrógeno del $90 \%$. Se observaron microalgas en todos los sistemas de cultivo durante los experimentos. Estas microalgas pueden afectar las mediciones de remoción de nutrientes en los sistemas debido a que son típicas de climas subtropicales y necesitan de los nutrientes inorgánicos para su crecimiento. A pesar de que todos los sistemas presentaron microalgas, es clara la diferencia en la remoción de nutrientes entre los tratamientos de control y los tratamientos con las plántulas de mangle. Por tal motivo, se cree que las microalgas no afectaron en gran medida los resultados obtenidos en este trabajo. Además, la variabilidad en la temperatura y salinidad no fueron factores limitantes en la tasa de remoción de nutrientes y crecimiento de los peces debido a que no se presentaron diferencias entre los tres tratamientos.

La asimilación de compuestos fosfatados en los humedales implica muchos caminos y es considerado un ciclo biogeoquímico complejo. Los principales mecanismos de reducción incluyen la sedimentación de partículas de fósforo, la adsorción del fósforo soluble en las partículas de arcilla y la asimilación por parte de las macrófitas acuáticas (Greenway y Woolley 1999). A pesar de que las concentraciones de $\mathrm{PO}_{4}^{-3}$ son menores comparadas con los compuestos nitrogenados en las pozas de acuacultura, el $\mathrm{PO}_{4}^{-3}$ es considerado un nutriente limitante en los bosques de mangle (Ye et al. 2001). El principal mecanismo de la reducción de compuestos fosfatados puede ser la asimilación por parte de las plantas de mangle (Greenway y Woolley 1999).

Una cantidad considerable de estudios han demostrado el uso de los mangles para la disminución de los nutrientes en ambientes costeros (e.g., Wong et al. 1997, Chu et al. 1998, Boonsong et al. 2003). Sin embargo, pocos estudios han hecho comparaciones entre diferentes especies de mangle (Yang et al. 2008, Ye et al. 2001), especialmente en zonas semiáridas. La remoción de nutrientes por L. racemosa y $R$. mangle en ambientes semiáridos puede ser menor comparada con la remoción por especies tropicales como Bruguiera gymnorrhiza, Rhizophora stylosa, A. corniculatum y K. candel (De-León-Herrera et al. 2015); sin embargo, al implementar un filtro de grava y arena en el fondo de los tanques experimentales del presente estudio, la remoción de nitrógeno por las plántulas de $L$. racemosa y $R$. mangle fue del $90 \%$, similar a la remoción por especies tropicales como K. candel (92.7\%) y B. gymnorrhiza (98\%) (Ye et al. 2001, 
Bowmer KH. 1987. Nutrient removal from effluents by an artificial wetland: Influence of rhizosphere aeration and preferential flow studied using bromide and dye tracers. Water Res. 21(5): 591-599. http://dx.doi.org/10.1016/0043-1354(87)90068-6

Buhmann A, Papenbrock J. 2013. Biofiltering of aquaculture effluents by halophytic plants: Basic principals, current uses and future perspectives. Environ. Exp. Bot. 92: 122-133. http://dx.doi.org/10.1016/j.envexpbot.2012.07.005

Camargo JA, Alonso A, Salamanca A. 2005. Nitrate toxicity to aquatic animals: A review with new data for freshwater invertebrates. Chemosphere 58(9): 1255-1267. http://dx.doi.org/10.1016/j.chemosphere.2004.10.044

Cardona-Olarte P, Twilley RR, Krauss KW, Rivera-Monroy V. 2006. Responses of neotropical mangrove seedlings grown in monoculture and mixed culture under treatments of hydroperiod and salinity. Hydrobiologia 569(1): 325-341. http://dx.doi.org/10.1007/s10750-006-0140-1

Chu HY, Chen NC, Yeung MC, Tam NFY, Wong YS. 1998. Tidetank system simulating mangrove wetland for removal of nutrients and heavy metals from wastewater. Water Sci. Technol. 38(1): 361-368.

De-León-Herrera R, Flores-Verdugo F, Flores-de-Santiago F, González-Farías F. 2015. Nutrient removal in a closed silvofishery system using three mangrove species (Avicennia germinans, Laguncularia racemosa, and Rhizophora mangle). Mar. Pollut. Bull. 91(1): 243-248. http://dx.doi.org/10.1016/j.marpolbul.2014.11.040

[FAO] Food and Agriculture Organization. 2012. The State of World Fisheries and Aquaculture 2010. FAO Fisheries and Aquaculture Department, Rome, 209 pp.

Flores-de-Santiago F, Kovacs JM, Flores-Verdugo F. 2012. Seasonal changes in leaf chlorophyll $a$ content and morphology in a subtropical mangrove forest of the Mexican Pacific. Mar. Ecol. Prog. Ser. 444: 57-68. http://dx.doi.org/10.3354/meps09474

Flores-Verdugo F, González-Farías F, Ramírez-Flores O, AmezcuaLinares A, Yáñez-Arancibia M, Alvarez-Rubio M, Day JW. 1990. Mangrove ecology, aquatic primary productivity, and fish community dynamics in the Teacapán-Agua Brava lagoonestuarine system (Mexican Pacific). Estuaries 13(2): 219-230. http://dx.doi.org/10.2307/1351591

Gersberg RM, Elkins BV, Goldman CR. 1983. Nitrogen removal in artificial wetlands. Water Res. 17(9): 1009-1014. http://dx.doi.org/10.1016/0043-1354(83)90041-6

Greenway M, Woolley A. 1999. Constructed wetlands in Queensland: Performance efficiency and nutrient bioaccumulation. Ecol. Eng. 12(1-2): 39-55. http://dx.doi.org/10.1016/S0925-8574(98)00053-6

Herbeck LS, Sollich M, Unger D, Holmer M, Jennerjahn TC. 2014. Impact of pond aquaculture effluents on seagrass performance in NE Hainan, tropical China. Mar. Pollut. Bull. 85(1): 190-203. http://dx.doi.org/10.1016/j.marpolbul.2014.05.050

$\mathrm{Hu} \mathrm{HY}$, Goto N, Fujie K, Kasakura T, Tsubone T. 2002. Reductive treatment characteristics of nitrate by metallic iron in aquatic solution. J. Chem. Eng. Japan 34(9): 1097-1102. http://dx.doi.org/10.1252/jcej.34.1097

Huang Q, Liu Y, Zheng X, Chen G. 2012. Phytoplankton community and the purification effect of mangrove in the mangrove plantation-aquaculture coupling systems in the Pearl River Estuary. Procedia Environ. Sci. 15: 12-21. http://dx.doi.org/10.1016/j.proenv.2012.05.004

Jensen F, Nielsen M, Nielsen R. 2014. Increased competition for aquaculture from fisheries: Does improved fisheries management limit aquaculture growth? Fish. Res. 159: 25-33. http://dx.doi.org/10.1016/j.fishres.2014.05.004
Huang et al. 2012). Por otro lado, las plántulas de $L$. racemosa y $R$. mangle presentaron resultados no satisfactorios respecto a la remoción de $\mathrm{PO}_{4}^{-3}$ (35-44\%). Consecuentemente, el entendimiento de los procesos relacionados con los mangles como exportadores o importadores de fosfato depende de la localidad y los factores ambientales, los cuales afectan las respuestas biológicas.

Las diferencias observadas en la remoción de nitrógeno disuelto por parte de las plántulas de L. racemosa y $R$. mangle indican que estos mangles de una región semiárida son capaces de remover una cantidad considerable de nitrógeno inorgánico en tanques con recirculación. Sin embargo, es necesario entender los procesos de transformación de nutrientes dentro de los mangles para poder optimizar los parámetros operacionales, los cuales incluyen el diseño físico y biológico de los sistemas de tratamiento.

\section{Agradecimientos}

El primer autor agradece apoyo financiero interno por parte del Instituto Politécnico Nacional de México. El segundo autor agradece financiamiento otorgado para las salidas de campo por el Instituto de Ciencias del Mar y Limnología, Universidad Nacional Autónoma de México (UNAM). El cuarto autor agradece financiamiento otorgado por la Dirección General de Asuntos del Personal Académico (DGAPA-UNAM). Se agradece a MN Herrera-Moreno el apoyo otorgado durante el análisis de laboratorio.

Kim J, Benjamin MM. 2004. Modeling a novel ion exchange process for arsenic and nitrate removal. Water Res. 38(8): 2053-2062.http://dx.doi.org/10.1016/j.watres.2004.01.012

Krauss KW, Doyle TW, Twilley RR, Rivera-Monroy VH, Sullivan JK. 2006. Evaluating the relative contributions of hydroperiod and soil fertility on growth of south Florida mangroves. Hydrobiologia 569(1): 311-324. http://dx.doi.org/10.1007/s10750-006-0139-7

Kristensen E, Bouillon S, Dittmar T, Marchand C. 2008. Organic carbon dynamics in mangrove ecosystems: A review. Aquat. Bot. 89(2): 201-219.

http://dx.doi.org/10.1016/j.aquabot.2007.12.005

Lin YF, Jing SR, Lee DY, Wang TZ. 2002. Nutrient removal from aquaculture wastewater using a constructed wetlands system. Aquaculture 209: 169-184. http://dx.doi.org/10.1016/S0044-8486(01)00801-8

Lin YF, Jing SR, Lee DY. 2003. The potential use of constructed wetlands in a recirculating aquaculture system for shrimp culture. Environ. Pollut. 123(1): 107-113. http://dx.doi.org/10.1016/S0269-7491(02)00338-X

Maltais-Landry G, Maranger R, Brisson J, Chazarenc F. 2009. Nitrogen transformations and retention in planted and artificially aerated constructed wetlands. Water Res. 43(2): 535-545. http://dx.doi.org/10.1016/j.watres.2008.10.040

Menkouchi Sahli MA, Tahaikt M, Achary I, Taky M, Elhanouni F, Hafsi M, Elmghari M, Elmidaoui A. 2006. Technical optimization of nitrate removal for groundwater by ED using a pilot plant. Desalination 189: 200-208.

http://dx.doi.org/10.1016/j.desal.2005.06.025 
Monroy-Torres M, Flores-Verdugo F, Flores-de-Santiago F. 2014. Growth of three subtropical mangrove species in response to varying hydroperiod in an experimental tank. Cienc. Mar. 40(4): 263-275. http://dx.doi.org/10.7773/cm.v40i4.2455

Moroyoqui-Rojo L, Flores-Verdugo F, Hernández-Carmona G, Casas-Valdez M, Cervantes-Duarte R, Nava-Sánchez EH. 2012. Nutrient removal using two species of mangrove (Rhizophora mangle and Laguncularia racemosa) in experimental shrimp (Litopenaeus vannamei) culture ponds. Cienc. Mar. 38(2): 333-346.

Páez-Osuna F, Gracia A, Flores-Verdugo F, Lyle-Fritch LP, AlonsoRodríguez R, Roque A, Ruiz-Fernández AC. 2003. Shrimp aquaculture development and the environment in the Gulf of California ecoregion. Mar. Pollut. Bull. 46(7): 806-815. http://dx.doi.org/10.1016/S0025-326X(03)00107-3

Paniagua-Michel J, Garcia O. 2003. Ex-situ bioremediation of shrimp culture effluent using constructed microbial mats. Aquacult. Eng. 28: 131-139. http://dx.doi.org/10.1016/S0144-8609(03)00011-6

Reed SC, Crites RW, Middlebrooks EJ. 1995. Wetland Systems. Natural Systems of Waste Management and Treatment. 2nd ed. McGraw-Hill, New York, pp. 173-284.

Reef R, Feller IC, Lovelock CE. 2010. Nutrition of mangroves. Tree Physiol. 30(9): 1148-1160. http://dx.doi.org/10.1093/treephys/tpq048

Saenger P. 2002. Mangrove Ecology, Silviculture and Conservation. Kluwer Academic Publisher, Dordrecht, 360 pp.

Schneider O, Sereti V, Eding EH, Verreth JAJ. 2005. Analysis of nutrient flows in integrated intensive aquaculture systems. Aquacult. Eng. 32: 379-401. http://dx.doi.org/10.1016/j.aquaeng.2004.09.001

Schoeman JJ, Steyn A. 2003. Nitrate removal with reverse osmosis in a rural area in South Africa. Desalination 155(1): 15-26. http://dx.doi.org/10.1016/S0011-9164(03)00235-2

Shimoda T, Fujioka Y, Srithong C, Aryuthaka C. 2007. Effect of water exchange with mangrove enclosures based on nitrogen budget in Penaeus monodon aquaculture ponds. Fish. Sci. 73(2): 221-226. http://dx.doi.org/10.1111/j.1444-2906.2007.01327.x

Sison NF, Hanaki K, Matsuo T. 1995. High loading denitrification by biological activated carbon process. Water Res. 29(12): 2776-2779. http://dx.doi.org/10.1016/0043-1354(95)00119-6

Strickland JD, Parsons TR. 1972. A Practical Handbook of Seawater Analysis. Fisheries Research Board of Canada Bulletin 167, $310 \mathrm{pp}$.
Sundareshwar PV, Morris JT, Koepfler EK, Fornwalt B. 2003. Phosphorus limitation of coastal ecosystem processes. Science 299(5606): 563-565. http://dx.doi.org/10.1126/science. 1079100

Tam NFY, Wong YS. 1995. Mangrove soils as sinks for wastewaterborne pollutants. Hydrobiologia 295(1): 231-241. http://dx.doi.org/10.1007/bf00029130

Tam NFY, Wong AHY, Wong MH, Wong YS. 2009. Mass balance of nitrogen in constructed mangrove wetlands receiving ammonium-rich wastewater: Effects of tidal regime and carbon supply. Ecol. Eng. 35(4): 453-462. http://dx.doi.org/10.1016/j.ecoeng.2008.05.011

Tanner CC, Clayton JS, Upsdell MP. 1995. Effect of loading rate and planting on treatment of dairy farm wastewaters in constructed wetlands. II. Removal of nitrogen and phosphorus. Water Res. 29(1): 27-34. http://dx.doi.org/10.1016/0043-1354(94)00140-3

Wong YS, Tam NFY, Chen GZ, Ma H. 1997. Response of Aegiceras corniculatum to synthetic sewage under simulated tidal conditions. Asia-Pacific Conference on Science and Management of Coastal Environment. Dev. Hydrobiol. 123: 89-96. http://dx.doi.org/10.1007/978-94-011-5234-1_10

Wu Y, Chung A, Tam NFY, Pi N, Wong MH. 2008. Constructed mangrove wetlands as secondary treatment system for municipal wastewater. Ecol. Eng. 34(2): 137-146. http://dx.doi.org/10.1016/j.ecoleng.2008.07.010

Yang Q, Tam NFY, Wong YS, Luan TG, Su WS, Lan CY, Shin PKS, Cheung SG. 2008. Potential use of mangroves as constructed wetland form municipal sewage treatment in Futian, Shenzhen, China. Mar. Pollut. Bull. 57: 735-743.

http://dx.doi.org/10.1016/j.marpolbul.2008.01.037

Ye Y, Tam NFY, Wong YS. 2001. Livestock wastewater treatment by a mangrove pot-cultivation system and the effect of salinity on the nutrient removal efficiency. Mar. Pollut. Bull. 42(6): $512-520$. http://dx.doi.org/10.1016/S0025-326X(00)00196-X

Zaitsev G, Mettänen T, Langwaldt J. 2008. Removal of ammonium and nitrate from cold inorganic mine water by fixed-bed biofilm reactors. Miner. Eng. 21(1): 10-15. http://dx.doi.org/10.1016/j.mineng.2007.08.014

Zhang JE, Liu JL, Ouyang Y, Liao BW, Zhao BL. 2010. Removal of nutrients and heavy metals from wastewater with mangrove Sonneratia apetala Buch-Ham. Ecol. Eng. 36(6): 807-812. http://dx.doi.org/10.1016/j.ecoleng.2010.02.008

Received March 2015, accepted September 2015. 